\title{
Managing Trust of E-customers in Online Shopping - A Case Study of Saudi Arabia
}

\author{
Dr. Zaid Ahmad Ansari \\ Associate Professor of Marketing \\ College of Business and Economics, Qassim University, Saudi Arabia
}

\begin{abstract}
Purpose: Developing countries are still dealing with basic issues in promoting online shopping. One such issue faced by ecommerce since inception is the lack of trust of the e-customers about the overall online shopping concept. Saudi Arabia is the largest economy in the middle east going through huge reforms in economic and social areas. The main aim of the current study was to explore the level of importance a Saudi e-customer puts on trust in online shopping to motivate them to adopt it.

Methodology: The study is descriptive and quantitative based on primary data collected from respondents including Saudis and non-Saudis living in Saudi Arabia. Data was collected by close-ended structured questionnaire. The intensity of response on importance of trust was taken on five point Likert scale. To encourage high response rate and reliable data the English questionnaire was translated into Arabic language as it is the spoken language of the country. To get the results to satisfy the objectives of the study, following statistics analyzed the primary data namely mean, frequency, percentage, and t-test to measure the difference between the Saudis and Non-Saudis.

Implications: The results will be useful for the e-retailers especially in Saudi Arabia and middle-east and also outside the region. The e-retailers can understand the concern area of e-customers and thus plan to minimize it to build e-customers trust.
\end{abstract}

Limitations: The study is based on data from Saudi Arabia, therefore for generalization of the findings the same study may be conducted in other regions.

Keyword: E-retailer, E-consumer, Trust, online shopping, Saudi Arabia

DOI: $10.7176 / \mathrm{EJBM} / 11-6-06$

\section{INTRODUCTION}

Global sales over internet are growing so fast that solid estimates of their volume are hard to come by. Various highly optimistic forecasts by many agencies have been given about the expected increase in online sales. Trust is the belief that another can be relied upon with confidence to perform role and responsibilities in a fiduciary manner - and is manifest in a willingness to voluntarily increase one's vulnerability to another. Trust is the extent to which the customer believes that the vendor has intentions and motives that are beneficial to the customer and the vendor is concerned with creating positive customer outcomes (Jarvenpaa and Naom 1999; Cazier et al., 2006; SanchezFranco et al., 2010; Goles et al., 2009). Trust, "a willingness to rely on an exchange partner in whom one has confidence" (Moorman et al., 1992) is central to e-shopping intentions (Fortin et al., 2002; Goode and Harris, 2007; Lee and Turban, 2001). E-shopping is conducted in virtual environment with no physical demonstration and evaluation of the product. Therefore, trust in e-retailer plays important role in convincing the e-customers to shop online. Since online shopping is completed in a situation where e-customers and e-retailers are distant apart from each other the e-customers very often lack confidence (trust) as to the delivery, quality, delivery time, safety and security of the payment, and personal information and many other concerns may prevent the e-customers from shopping online. Such lack of perceived trust is the biggest obstacle to e-commerce transactions (Hoffman et. al., 1999; Pavlou et al. 2007). In fact, perceived trust is one of the most important prerequisites for consumers to make trading decisions (Gefen et al. 2003; Pavlou and Gefen 2004). Customer prefer a more reliable service to a faster and easier one. This result shows once again that trust-related issues are important determinants of ecommerce diffusion in Arab countries. Consumer further agree with business managers on the importance of issues such as Internet security, consumer's privacy, trust, and service quality (Adel, 2003).

However, the online shopping developed in western countries like USA, and Europe by leap and bound motivating the academicians, researchers and managers alike in investigating its evolving contemporary issues as suggesting timely and effective solutions. The challenge with the e-retailers was to convince the e-customers that nothing is going to be wrong. In their study the researchers simply investigated and found out what were the concerns of ecustomers that could have prevented them from buying online. In other words, investigated e-customers trust factors in online shopping. Thus earlier researches strongly show that trust is an antecedent to online shopping. But the concern is what could be the areas where the e-customers trust should be build up. In the following section of literature review earlier researches that attempted to find out factors of concerns for e-customers are analyzed.

\section{REVIEW OF LITERATURE}


The subject of ecommerce has been hugely researched in pioneering countries namely USA, and European countries. However, the subject remained under explored in countries like Saudi Arabia including other middleeast countries. This section devoted to review the existing literature concerning the trust aspect of the e-consumers. Indeed, consumer are exposed to different levels of risks depending on the modes of shopping, which increases the more the consumer is separated from the physical presence of the retail store (Hawes \& Lumpkin, (1986) such as in online shopping making e-customers trust is important evident by the findings of researches such as Hsu and Chen (2014), Pavlou (2003), Lu et. al., (2010). Trust leads to positive intention towards transaction behaviors in online shopping Hsu and Chen (2014), trust in the vendor can positively affect shoppers' attitude and intention towards the online sellers Pavlou (2003), perceived trust of online shop positively influences the future e-purchase intention and considered as a critical factor for conducting e-commerce transactions, Lu et al (2010). Chen and Huang (2013) e-customer's intention to purchase from an e-retailer has three dimensions namely; first making a purchase can be considered to be a form of risk. Second, making a purchase can be considered to constitute a form of relationship, and third, purchase intention is a proxy of making an actual purchase, therefore customer's trust in general can reduce perceived risk and increases the intention of purchase (Pavlou and Gefen, 2004). Thus the eretailer's success somehow is dependent on the level of trust an e-customer pose in the concept of shopping online in general and in the particular e-retailer with whom he has to transact. Some of the major concern areas of the ecustomers are attack from hackers. They attack, identity of the e-customers, credit card fraud, fishing for sensitive information and non-delivery of the merchandise are important issues of concern growing in number as well as in geographical reach (Bhattacharya et al., 2011; Demery, 2010; Gravish \& Tucci, 2006; Gravish, 2008; Ries, 2010). The challenge of building e-customers trust is enhanced by some facts in the area. The Federal Bureau of Investigation's (FBI) Internet crime compliant center received 3.4\% more complaint submissions in 2011 as compared to 2010, which accounts for a total loss of $\$ 485.3$ million (Internet Crime Report, 2009). Such online fraud statistics concerning the risks of cybercrime may result in a lack of consumers' trust which in turn negatively affects their decisions to shop online (Chen \& Dibb, 2010; Gefen et cl., 2003; Kukar-Kinney \& Close, 2010).

Since the online transaction takes place in an environment where the parties involved are far from each other without any physical demonstration of the product, another aspect of trust in online marketing is an e-consumers' perceived reliability on the brand, products, or services of vendors (Gefen et al., 2008). The product quality is a focal reason for consumers to buy product via the internet (Aaker, D.A., 1991). Norazah (2006) stated that the reliability of the products or services offered through internet attracted Malaysian internet users to conduct online shopping. Haque and Khatibi (2006) revealed that online products' price significantly influenced the frequency level of online shopping activities. Price, product quality, and variety are important factors for online shopping (Rust, et. al., 2000). People are increasingly relying on web based commercial information for electronic commerce transactions that range from small personal items to home purchases (Horrigan, 2008).

Another major area of concern for the e-customers is regarding the safety and security of personal information and financial information on the internet (Bart et al., 2005; Jones and Vijayasarathy, 1998). Kolsaker and Payne (2002) maintain that security reflects perceptions regarding the reliability of the payment methods used and the mechanisms of data transmission and storage. A large number of researches show e-purchase intentions negatively influenced by perceived risk of electronic transactions in e-commerce (Martin et al., 2011; Polasik and Eisniewski 2009; and Lepp et al., 2011; Cho, 2010; 27 and 28; Dong-Her, 2004; Flavian and Guialy'u, 2006). Privacy is a critical factor in acquiring potential online customers and retaining existing customers (Park and Kim, 2003). Thus from the above literature review it is important that trust of the e-customers in various aspects of online shopping such as information provided, product, quality and brand, safety and security of personal information, financial information, privacy etc., play very important role in e-customer online behaviour.

From a consumers' perspective, the use of information communication technologies offers a number of benefits, including efficiency, convenience, richer and participative information, a broader selection of products, competitive pricing, cost reduction, and product diversity (Bayo-Moriones \& lera-Lopez, 2007).

\section{OBJECTIVE}

The main objective of the current study was to find out the importance of trust on various aspects in online shopping such as safety and security of personal information, financial information, quality of product, delivery of product and many others for the e-customers.

\section{METHODOLOGY}

The objective of this study was addressed by using a quantitative research strategy, based on questionnaire survey of the people living in Saudi Arabia. Empirical data was collected from citizens of Saudi Arabia. The respondents included Saudis and Non Saudis. Convenience random sampling strategy was used to administer the questionnaires. The participants were mainly associated with the part-time bachelors' program of King Abdulaziz University in Jeddah. The questionnaires were administered to the participants when they came for counseling classes of the study and also during the final exams. The participants were from different parts of Saudi Arabia 
thus representative of country. The responses were collected from four hundred respondents.

Various factors of concerns in online shopping were identified such as e-customers trust regarding product quality, safe delivery, delivery in time, reliability of the information, safety and security of personal information, financial information, privacy. The respondents were asked the following question "Do you think your trust in online shopping for the following features will encourage you to buy online?" Thus the question intended to find out the impact and importance of the features in online shopping.

Descriptive analytical tools such as mean and standard deviation were used to summarize the respondents' feedback. Reliability test was done by Cronbach Alpha analysis. T-test was applied to establish the significance level about the importance of trust in online shopping between Saudis and Non-Saudis. In the following sections empirical results are presented and discussed.

\section{EMPIRICAL RESULTS \\ Reliability Test}

According to (DeVellis, 1991) Cronbach alpha scores above 0.60 are acceptable, the alpha value in current research for the data is very high which is 0.956 for the 9 items investigated. Thus the data is highly reliable.

\section{Importance of Trust for E-customers in Online Shopping}

The trust of customers in online shopping is very important in influencing the decision of buying online. If a customer trusts in these features they may buy online otherwise not. For all the nine variables of trust under investigation the mean values were more than 4 strongly indicating that customer trust in these factors were important. Table 2 presents the variables a customer needs to trust in online shopping. The results were as follows; Product quality - 4.49; Reliability of the overall transaction - 4.41; Safe delivery of the purchased product - 4.38; Time taken in delivering the shopped product - 4.29; Competitive price - 4.32; Correct information on the store 4.30; Safety of the computer - 4.27; Security of personal information - 4.30; Safety of the financial information 4.30. Thus, the influence of trust is very strong, hence an e-retailer must focus on building e-customers' trust. Next section presents a comparison of importance of trust in online shopping between and Saudi e-customers and NonSaudi E-customers.

\section{Comparison of Importance of Factors Influencing Trust in Online Shopping: Saudi E-customers versus} Non Saudi E-customers

The objective of this section was to compare the importance of various online features under investigation for ecustomers by their nationalities classified as Saudi E-customer and Non Saudi E-customers. This comparison is important as it would indicate that experience of the e-customers as it is believed that with experience the ecustomers build trust and subsequently the fear in the overall online shopping system develops. Online shopping is done in virtual environment without the buyers and sellers coming face to face contact. Thus the entire transaction depends on trust of each other. The mean value results in table 3 show the difference in importance for Saudis e-customers and Non Saudi e-customers. The mean value for all the nine features are more than 4 in both the nationalities indicating trust in online shopping is important for all e-customer irrespective of nationality to transact online. On comparison of the mean values, the results indicated that mean values for all the nine online features for Saudi e-customers were more than Non Saudi e-customers. This indicates that the local e-customers fear more than expatriate e-customers, they lack confidence in online shopping. Therefore, the e-retailers need to focus on building trust of these e-customers through various strategies such as guarantee, education of the ecustomers. Ones the e-customers trust is build there could be surge in online business in Saudi Arabia as enablers of online shopping are strong here (Ansari, 2016). The results in table 3, were statistically significant for the Product quality significant at .056; 'Delivery time statistically significant at .057, Correct Information statistically significant at .050 , indicating that the e-customers trust in the product quality, delivery time, and correct information were extremely important for them to shop online.

\section{DISCUSSIONS}

The main objective of this study was to find out the importance of trust in various online shopping features for ecustomers to transact with online and the accompanying objective was to find out the difference between the Saudi and Non Saudi e-customers. The results in above sections sufficiently explained the objective. Like previous studies which showed that e-customers trust is important Hsu and Chen (2014), Pavlou (2003), Lu et. al., (2010), the findings of the current study also strongly support that trust of e-customers in general in Saudi Arabia is also very important. It was evident by the high mean values of all the nine online shopping features investigated where the e-customers feared as to what may happen such as whether the e-retailer will send the selected quality of the product, whether the overall idea of online shopping was reliable, whether the products will be delivered safely, whether the shopped products will be delivered in time. Not only that the e-customers also needed to trust that the price of online shopping is competitive as it promises lower prices as compared to traditional shopping. The 
information on the online store is the only interface between the e-customers and the e-retailers therefore they depend solely on the information provided on the online store regarding the product quality, features, price, delivery, payment etc. Therefore, the correctness of the information is very important for the e-customers in decision making, which is again indicated by high mean value. Other major concerns of the e-customers were regarding safety and security of the computer on which they transact, of their personal information, and the financial information while online shopping (Bart et al., 2005; Jones and Vijayasarathy, 1998; Kolsaker and Payne 2002). A large number of researches show e-purchase intentions negatively influenced by perceived risk of electronic transactions in e-commerce (Martin et al., 2011; Polasik and Eisniewski 2009; and Lepp et al., 2011; Cho, 2010; 27 and 28; Dong-Her, 2004; Flavian and Guialy'u, 2006). The e-customers in Saudi Arabia feel the risk in transacting online. Thus they need to trust that online transaction is safe and secure indicated again by high mean value.

As for the second objective the results in table 3 showed that Saudi e-customers perceived risk in online shopping in comparison to other nationals is high. They fear relatively more and statistically significant for the products quality, delivery time, and correctness of the information given on the online store. Therefore, to accelerate the growth of online business in Saudi Arabia trust building is important. The e-retailers may focus especially on trust building programs such as educating the e-customers for the concerned areas. They try to build the trust of the customers by highlighting such features such as cash on delivery, return policy, their own payment systems. As shown by Ansari 2016, that Said Arabia as a whole has strong enablers of online shopping such as possession of gadgets namely smart phones, laptops, and use of internet that are necessary for online shopping.

\section{CONCLUSION}

Like large number of researches done earlier the current research also showed that trust of e-customers is very important in convincing them in online shopping. The results strongly support indicated by high mean value for all the investigated variables. The concerns of the e-customers were natural and logical as the entire transaction is done in absence of physical environment face to face interactions where the customers personally check and ensures all the required information before buying in traditional face to face shopping. It all matter of trust. Also from the results it can safely be said that Saudi E-customers level of trust in online shopping is less in comparison to Non-Saudi e-customers.

\section{MANAGERIAL IMPLICATIONS}

The findings provide first-hand information directly from current and future ecustomers which can be used by the companies in general and marketing managers in particular in formulating their marketing strategies. The findings can be an extremely useful tool for marketers in attracting, retaining, and growing ecustomers. The finding of the current research will help the e-retailer to plan and replan their strategies to attract new e-customers and retain existing e-customers for repeat purchase.

\section{ACKNOWLEDGEMENT}

This project was funded by the Deanship of Scientific Research (DSR) University of Jeddah, Jeddah, under grant no. (1436/849/304). The authors, therefore, acknowledge with thanks DSR technical and financial support.

\section{REFERENCES}

Aaker, D. A. (1991). Managing brand equity: capitalizing on the value of a brand name, New York: Free Press. Adel M. A. (2003). Key Internet characteristics and e-commerce issues in Arab countries. Information Technology \& People, 16 (1), pp. 9- 20.

Ahmad, N., Omar, A., and Ramayah, T. (2010). Consumer lifestyles and online shopping continuance intention. Business Strategy Series, 11 (4), pp. 227 - 243.

Ansari, Z.A., and Hazemi, A. R. (2016). An empirical study of the consumer awareness and acceptance of online shopping in Saudi Arabia. International Journal of Development Research, 6 (2), pp. 6918 - 6925.

Arthur, C., and Halliday, J. (2010). Amazon UK goes offline amid threats of cyber-attacks, Guardian.co.uk. Available at: http://www.guardian.co.uk/technology/2010/dec/12/amazon-uk-offline-christmas . (December 20, 2010).

Bayo-Moriones, A., and Lera-Lopez, F. (2007). A firm-level analysis of determinants of ICT adoption in Spain. Technovation, 27 (6/7), pp. $352-366$.

Bhattacharya, S., Jha, S., Tharakunnel, K., and Westland, J.C. (2011). Data mining for credit card fraud: A comparative study. Decision Support Systems, 50 (3), pp. $602-613$.

Chen, J., and Dibb, S. (2010). Consumer trust in the online retail context: Exploring the antecedents and consequences. Psychology and Marketing, 27 (4), pp. 323 - 346.

Chen, M.F, and Huang, C. H. (2013). The impacts of the food traceability system and consumer involvement on consumers' purchase intentions toward fast foods. Food Control, 33(2): pp. $313-319$. 
Cho S. (2010). Perceived risks and customer needs of geographical accessibility in electronic commerce. Electronic Commerce Research and Applications, 9, pp. 495-506.

Demery, P. (2010). Hackers attack e-retailers on peak shopping days" Internet.com, Available at: http://www.internetretailer.com/2010/12/16/hackers-attack-e-retailers-peakshopping- (December, 20, 2017).

Gefen, D., Benbasat, I. and Pavlou, P. (2008). A research agenda for trust in online environment. Journal of Management Information Systems, 24 (4), pp. 275 - 286.

Gefen, D., Karahanna, E., and Straub, D.W. (2003). Trust and TAM in online shopping: An integrated model. MIS Quaterly, 27 (1), pp. $51-90$.

Gefen, D., Karahanna, E., and Strauss, D.W. (2003). Trust and TAM in online shopping: An integrated model. MIS Quaterly, 27 (1), pp. 51 - 90.

Gravish, B. and Tucci, C. L. (2006). Fraudulent auctions on the Internet. Electronic Commerce Research. 6 (2), pp. $127-140$.

Gravish, B. and Tucci, C. L. (2008). Reducing internet auction fraud. Communications of the ACM, 51(5), pp. 80 $-97$.

Griffith, E. (2008). Amazon.com website down. AppScout.com. Available at: http://www.appscout.com/2008/06/amazoncom_web_site_down.php. (December 20, 2017).

Haque, A., and Khaitibi, A. (2006). The study of the behaviour of Malaysian consumers towards online shopping. Asian Journal of Information Technology, 5 (1), pp. 12 - 19.

Hawes, J., \& Lumpkin, J. (1986). Perceived risk and the selection of a retail patronage mode. Journal of Academy of Marketing Science, 14 (4), pp. 37 - 42.

Horrigan, J. (2008). The internet and consumer choice. Pew Internet \& American Life Project report. Available at: http://www.pewinternet.org/Reports/2008/The-Internet-and-Consumer-Choice.aspx, (June 8, 2010).

Hsu, C.L. and Chen, M. C. (2014). Explaining consumer attitudes and purchase intentions toward organic food: Contributions from regulatory fit and consumer characteristics. Food Quality Preference, 35, pp. 6 - 13.

Internet Crime Complaint Center (IC3), Internet Crime Report FBI IC3. (2009). Available at: http://www.ic3.gov/media/annualreports.aspx. (December 20, 2010).

Internet Crime Complaint Center, (IC3) Internet Crime Report, FBI IC3. (2009). Available at: http://www.ic3.gov/media/annualreports.aspx. (December 20, 2010).

Kim, D.J., Ferrin, D. L. and Rao, H.R. (2008). A trust based consumer decision making model in electronic commerce: The role of trust, perceived risk and their antecedents. Decision Support System. 44 (2), pp. 544 - 564. Kukar-Kinney, M. and Close, A.G. (2010). The determinants of consumers online shopping cart abandonment. Journal of Academy of Marketing Science, 38 (2), pp. 240 - 250.

Lepp, A., Gibson, H. and Lane, C. (2011). Image and perceived risk: A study of Uganda and its official tourism. Tourism Management, 32, pp. 675- 684.

Lu, Y., Zhao, L. and Wang, B. (2010). From virtual community members to C2C e-commerce buyers: Trust in virtual communities and its effect on consumers' purchase intention. Electronic Commerce Research and Applications, 9, pp. 346- 360.

Martin, S., Camarero, C. and Jose R. (2011). Dual effect of perceived risk on cross-national e-commerce, Internet Research, 21, pp. 46-66.

McKnight, D.H., Choudhury, V. and Kacmar, C. (2002). Developing and validating trust measures for ecommerce: An integrative typology. Information System Research, 13 (3), pp. 334 - 359.

Moore, T., Clayton, R., and Anderson, R. (2009). The economics of online crime. Journal of Economic Perspectives, 23 (3), pp. $3-20$.

Norazah, M.S. (2006). A descriptive investigation of Malaysian Internet users' adoption of online shopping. AsiaPacific Journal of Information Technology and Multimedia, 3, pp. 127 - 138.

Pavlou, P.A., and Gefen, D. (2004). Building effective online marketplaces with institution-based trust. Information Systems Research, 15 (1), pp. 37 - 59.

Polasik, M and Eisniewski, T. (2009). Empirical analysis of internet banking adoption in Poland. International Journal of Bank Marketing, (27), pp. 32- 52.

Ries, B. (2010). Hackers' most destructive attacks", The DailyBeast.com. Available at: http://www.thedailybeast.com/blogs-and-stories/2010-12-11/hackers-10-most-famous-attacks-worms-and-ddostakedowns/. (December 20, 2010).

Rust, R. T., Zeithalm, V. A., and Lemon, K.N. (2000). Driving customer equity: how customer lifetime value is reshaping corporate strategy. New York: Free Press. 
Tables and Figures

Table - 1; Cronbach Alpha Reliability Test

\section{TRUST}

Product Quality

Reliability

Safe delivery

Delivery time

Competitive price

Correct information

Safety of the computer

Security of personal information

Safety of the financial information

Table 2 :Trust Features in online shopping

\begin{tabular}{|l|c|c|c|c|c|c|c|}
\hline & Mean & Std. & \multicolumn{5}{|c|}{ Percent of respondents } \\
\cline { 5 - 8 } & & Dev & SA & A & SWA & DA & SDA \\
\hline Product Quality & 4.49 & 0.973 & 72.25 & 13.00 & 8.50 & 3.75 & 2.50 \\
\hline Reliability & 4.41 & .969 & 64.50 & 20.25 & 10.00 & 2.25 & 3.00 \\
\hline Safe delivery & 4.38 & 1.026 & 65.75 & 16.00 & 12.25 & 2.50 & 3.50 \\
\hline Delivery time & 4.29 & 1.052 & 59.00 & 21.75 & 12.00 & 3.50 & 3.75 \\
\hline Competitive price & 4.32 & 1.022 & 59.25 & 23.50 & 10.50 & 3.25 & 3.50 \\
\hline Correct information & 4.30 & 1.009 & 58.00 & 23.75 & 11.75 & 3.50 & 3.00 \\
\hline Safety of the computer & 4.27 & 1.048 & 57.75 & 22.00 & 12.75 & 4.25 & 3.25 \\
\hline Security of personal information & 4.30 & 1.018 & 58.50 & 22.25 & 12.00 & 4.75 & 2.50 \\
\hline Safety of the financial information & 4.30 & 1.066 & 61.25 & 18.50 & 11.75 & 5.50 & 3.00 \\
\hline
\end{tabular}

Table 3: E-customers' Trust in online shopping by nationality

\begin{tabular}{|l|r|r|r|r|r|r|r|}
\hline Trust & \multicolumn{2}{|c|}{ Saudi } & \multicolumn{2}{c|}{ Non-Saudi } & t-test & df & Sig. (2-tailed) \\
\hline & Mean & Std. Dev & Mean & Std. Dev & & & \\
\hline Product Quality & 4.52 & .955 & 4.25 & 1.058 & 1.918 & 398 & .056 \\
\hline Reliability & 4.44 & .951 & 4.24 & 1.071 & 1.433 & 398 & .153 \\
\hline Safe Delivery & 4.41 & 1.017 & 4.18 & 1.073 & 1.545 & 398 & .123 \\
\hline Delivery Time & 4.33 & 1.048 & 4.04 & 1.053 & 1.912 & 398 & .057 \\
\hline Competitive Price & 4.34 & 1.025 & 4.18 & 1.002 & 1.060 & 398 & .290 \\
\hline Correct Information & 4.34 & .997 & 4.05 & 1.061 & 1.969 & 398 & .050 \\
\hline Safety of the Computer & 4.29 & 1.039 & 4.11 & 1.100 & 1.208 & 398 & .228 \\
\hline Security of Personal Information & 4.30 & 1.018 & 4.27 & 1.027 & .175 & 398 & .862 \\
\hline Safety of the Financial Information & 4.30 & 1.071 & 4.25 & 1.040 & .303 & 398 & .762 \\
\hline ** significant at 0.05 level & & & & & & & \\
\hline * significant at 0.10 level & & & & & & & \\
\hline
\end{tabular}




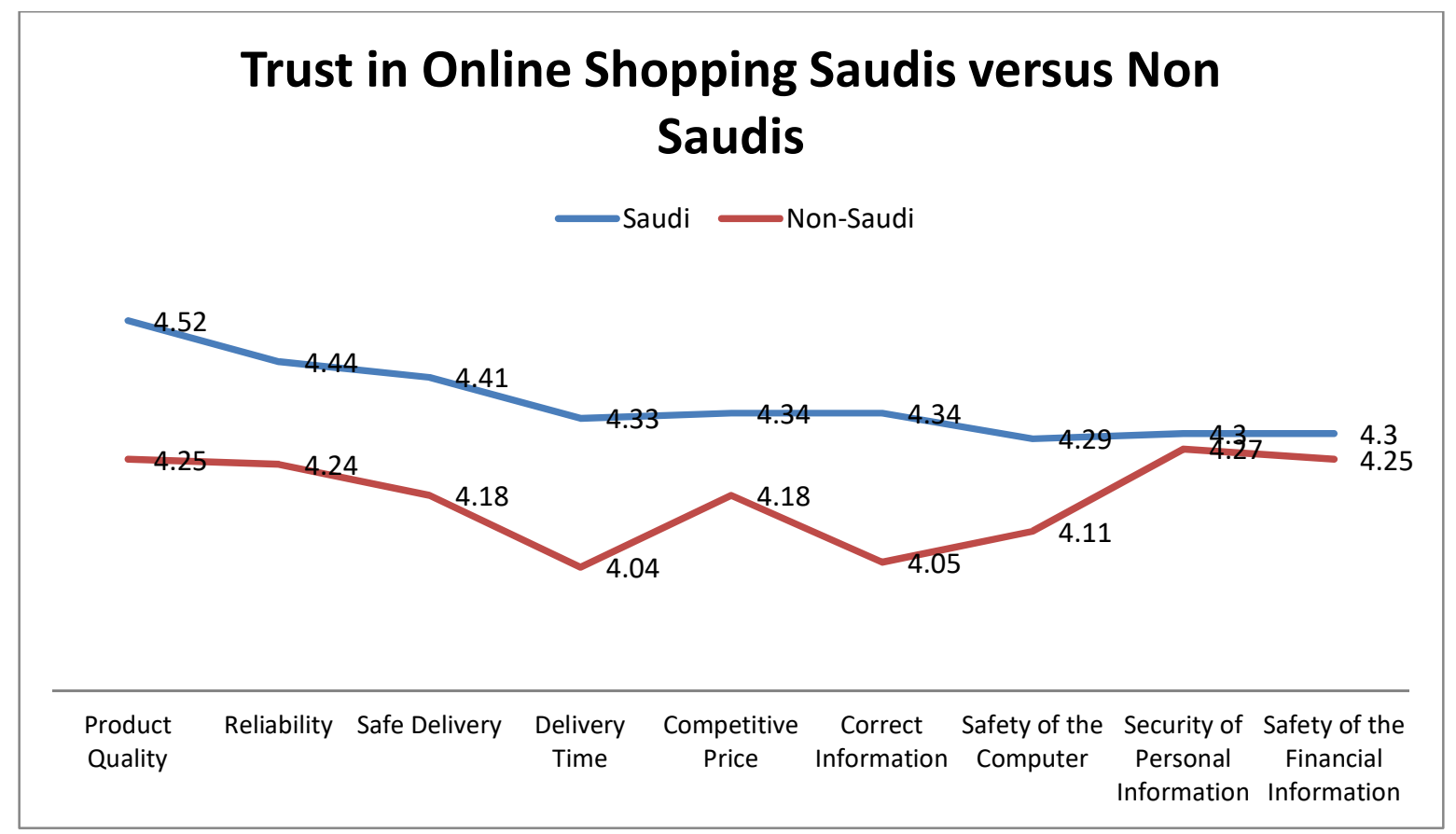

Figure-1

\section{Appendix}

Questionnaire

Q. Do you think your TRUST in online shopping for the following features will encourage you to buy online?

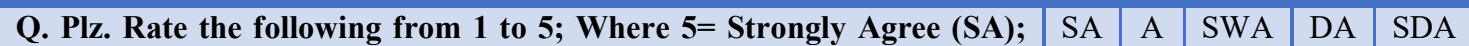
4=Agree (A); 3=Somewhat Agree (SWA); 2=Disagree (DA) and 1= Strongly Disagree (SDA)

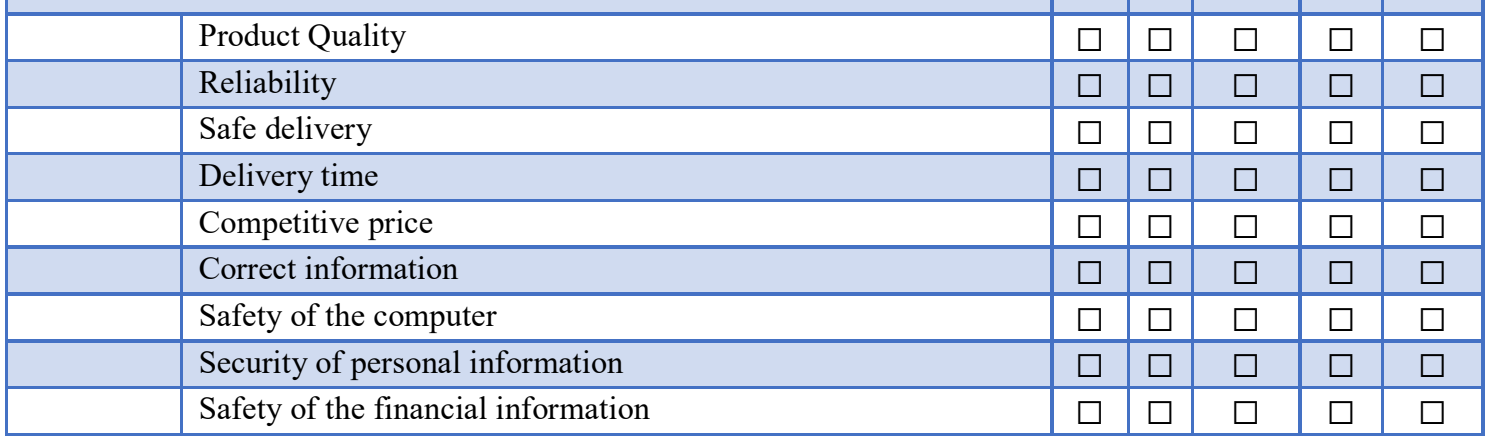

